NBER WORKING PAPER SERIES

\title{
LONG-RUN CONVERGENCE OF \\ ETHNIC SKILL DIFFERENTIALS
}

\author{
George J. Borjas
}

Working Paper No. 4641

\section{NATIONAL BUREAU OF ECONOMIC RESEARCH \\ 1050 Massachusetts Avenue \\ Cambridge, MA 02138 \\ February 1994}

The author is grateful to James Coleman, Daniel Hamermesh, Stephen Trejo, and Finis Welch for comments on an earlier draft. The research was supported by grants from the Russell Sage Foundation and the National Science Foundation. This paper is part of NBER's research program in Labor Studies. Any opinions expressed are those of the author and not those of the National Bureau of Economic Research. 
NBER Working Paper \#4641

February 1994

\title{
LONG-RUN CONVERGENCE OF \\ ETHNIC SKILL DIFFERENTIALS
}

\begin{abstract}
This paper investigates if the ethnic skill differentials introduced into the United States by the inflow of very dissimilar immigrant groups during the Great Migration of 1880-1910 disappeared during the past century. An analysis of the 1910,1940, and 1980 Censuses and the General Social Surveys revealed that ethnic differentials converge slowly. It might take four generations, or roughly 100 years, for the skill differentials introduced by the Great Migration to disappear. The analysis also indicates that the economic mobility experienced by Americanborn blacks resembles that of the white ethnic groups that made up the Great Migration.
\end{abstract}

George J. Borjas

Department of Economics, 0508 University of California at San Diego 9500 Gilman Drive La Jolla, CA 92093 and NBER 


\title{
LONG-RUN CONVERGENCE OF ETHNIC SKILL DIFFERENTIALS
}

\author{
George J. Borjas*
}

The extent to which ethnic differentials persist across generations is a central question in social science. The fact that ethnicity matters--and that it seems to matter for a very long time--is evident not only in the United States, but also throughout the many countries where long-dormant ethnic differences and conflicts are being reemphasized and rekindled.

Although economists have not traditionally been interested in questions relating to ethnic convergence, the issue has been a dominant topic in sociology. Beginning with the "melting-pot" hypothesis, which was a cornerstone of the original Chicago School of sociology, through the revisionist view of Glazer and Moynihan's (1963) classic Beyond the Melting Pot, two opposing models have been used to interpret the ethnic experience. The first argues that the melting pot indeed dissolves the differences among groups in one or two generations (Park, 1950; Gordon, 1964), while the second stresses the cultural, social, and economic differences that persist among ethnic groups. As Glazer and Moynihan (1963: xcvii) conclude: "The American ethos is nowhere better perceived than in the disinclination of the third and fourth generation of newcomers to blend into a standard, uniform national type."'

\footnotetext{
"George J. Borjas is Professor of Economics at the University of Califomia at San Diego and a Research Associale at the National Burenu of Economic Researeh. The author is graleful to James Coleman. Danict Hanicrniesh. Stephen Trejo. and Finis Welch for comments on an earlier draft. The research was supponed by grants from the Russell Sage Foundation and the National Science Foundation.

1 The debate over which of the two hypotheses better explains the data continues in the sociolog: litcrature. For instance. Alba (1990) stresses the convergence that occurred among groups of European origin. while Farley (1990) and Lieberson and Waters (1988) note the ethnic skill differences docinienied in the 1980 Census. even among groups of European origin. See also Jiobu (1990). Sollors (1986). Perlmann (1988). and Steinberg (1989).
} 
This paper investigates if the ethnic skill differentials introduced into the U.S. labor market by the inflow of very dissimilar immigrant groups during the Great Migration of 1880-1910 disappeared during the past century. By using the 1910, 1940, and 1980 Public Use Samples of the U.S. Census, as well as data from the General Social Surveys (GSS), the paper provides an empirical analysis of the long-run rate of convergence of ethnic skill differentials. The empirical work uses the 1910 Census to document the skill differentials existing among the original immigrant groups. The 1940 and 1980 Censuses and the GSS are then used to document the skill differences among the ethnic groups composed of the children and grandchildren of the immigrants. Finally, the analysis compares the economic mobility experienced by American-born blacks to that of the white ethnic groups that made up the Great Migration.

\section{Tlıe Great Migration}

The migration of persons to the United States that occurred at the end of the 19 th Century and at the beginning of the 20th was historically unprecedented. ${ }^{2}$ Table 1 documents the seismic shift that the Great Migration had not only on the size of the immigrant flow, but also on the national origin composition of immigrants. ${ }^{3}$

Prior to the Great Migration, the size of the immigrant flow had reached a peak of 2.8 million persons in the decade between 1871 and 1880 . Due to a confluence of economic, social,

\footnotetext{
${ }^{2}$ Higham (1963) and Jones (1960) provide fascinating accounts of the social and political conscquences of this population flow

${ }^{3}$ Because the analysis presenıcd below uses the 1910 decennial Census 10 chamclerize the skills of turnof-the-celutury immigmnts it is imporiant to stress that the Greal Migration did not stop in 1910. An addilional 5.7 nillion persons migrated between 1911 and 1920 , and 2.3 nillion persons migraled between 1921 and 1924. when restrictive new immigration policies went into effect.
} 
TABLE 1

SIZE AND NATIONAL ORIGIN COMPOSITION OF IMMIGRATION, 1871-1910

Country
of Origin:
Austria-Hungary
Belgium
Canada
China
France
Germany
Greece
Ireland
Italy
Japan
Mexico
Netherlands
Norway
Sweden
Poland
Portugal
Romanla
Soviet Union
Turkey
United Kingdom

A11

1871.1880
73.0
7.2
383.6
123.2
72.2
718.2
.2
436.9
55.8
.1
5.2
16.5
95.3
115.9
13.0
14.1
.0
39.3
.4
548.0
2812.2

2812.2
Number of Immigrants (in 1000s)

$\begin{array}{rrr}1881-1890 & 1891-1900 & 1901-1910 \\ 313.7 & & \\ 20.2 & 592.7 & 2145.3 \\ 393.3 & 18.2 & 41.6 \\ 61.7 & 3.3 & 179.2 \\ 50.5 & 14.8 & 20.6 \\ 1453.0 & 30.8 & 73.4 \\ 2.3 & 505.2 & 341.5 \\ 655.5 & 16.0 & 167.5 \\ 307.3 & 388.4 & 339.1 \\ 2.3 & 651.9 & 2045.9 \\ 1.9 & 25.9 & 129.8 \\ 53.7 & 1.0 & 49.6 \\ 176.6 & 26.8 & 48.3 \\ 391.8 & 95.0 & 190.5 \\ 51.8 & 226.3 & 249.5 \\ 17.0 & 96.7 & -. \\ 6.3 & 27.5 & 69.1 \\ 213.3 & 12.8 & 53.0 \\ 3.8 & 505.3 & 1597.3 \\ 807.5 & 30.4 & 157.4 \\ & 271.5 & 526.0 \\ 5246.6 & 3687.6 & 8795.4\end{array}$

Source: U.S. Immigration and Naturalization Service (1991:48-40). For the years 1899-1910, data for Poland was included in Austria-Hungary, Germany, and the Soviet Union. 
and political factors in some source countries and in the United States, the number of immigrants increased rapidly over the next three decades. By the early 1900 s, 8.8 million persons migrated during a single decade. In fact, immigration accounted for over half of the change in the population and labor force of the United States between 1901 and 1910.

Equally important, the Great Migration originated mostly in countries that had not been important sources of immigrants prior to that point. For instance, during the 1870 s and 1880 s, three northwestern European countries-Germany, Ireland, and the United Kingdom--accounted for about 60 percent of immigrants, and Canada accounted for an additional 15 percent. By 1900-1910, nearly a quarter of the immigrants originated in Austria-Hungary (which at the time included large parts of present-day Poland), an additional quarter originated in Italy, and about 20 percent originated in the territories of what would eventually become the Soviet Union. The number of immigrants from the traditional source countries of Germany, Britain, and Ireiand declined not only relatively but absolutely. Although 1.5 million Germans immigrated during the 1880s, only 342 thousand Germans were part of the much larger 1900-1910 wave. Similarly, even though 808 thousand British citizens immigrated in the 1880 s, Britain sent only 526 thousand persons between 1900 and $1910^{4}$

I use the I/250 1910 Public Use Sample of the U.S. Census to document the differences among the ethnic groups that made up the Great Migration (see Strong et al, 1989, for a detailed

\footnotetext{
${ }^{4}$ The historic shifts in the number and national origin composition of immigrants in the 1880-1910 period were accompanied by substantial changes in the skill endowments of the immigrant fow (Douglas. 1919). The perceived or actual economic and social impact of these changes became a central issuc in the debate over immigration policy which culminated in the enactment of the nalional-origins quota system during the 1920 s. An interesting summary of the findings in the +1 -volume report of the Dillingham Commission is given by Jenks and Lauck (1917).
} 
description of the data). I restrict the analysis to working men aged $25-64$ in 1910.5 The native sample is restricted to white men born in the United States, while the immigrant sample contains all foreign-born men. Table 2 documents some of the differences between immigrants and natives revealed by the 1910 Census.

It is evident that the two groups were very different; they had different skills, lived in different areas, and performed different jobs. Although 37 percent of white native men worked in agricultural jobs, only 17 percent of immigrants (and merely 11 percent of those in the 1900-1910 wave) worked in agriculture. Immigrants were instead employed in manufacturing jobs: nearly half worked in the manufacturing sector, as opposed to only a quarter of the native workforce. Correspondingly, at a time when only 28 percent of natives resided in the 230 largest cities (with population over 25,000 ), over half of the immigrants resided in those cities. The "new immigration," therefore, was essentially an urban phenomenon at a time when the native population was overwhelmingly agricultural and resided outside urban areas.

Immigrants were also less skilled than natives. One quarter of the immigrants present in the United States in 1910 (and over a third of those in the 1900-1910 wave) were laborers, while only 1 I percent of white natives employed outside agriculture were laborers. In addition, 96 percent of natives were literate (i.e., knew how to read and write any language), but only 87 percent of immigrants, and 77 percent of the immigrants in the $1900-1910$ wave, were literate.

\footnotetext{
'The analysis below uses avernge earuings in the worker's occupation to measure the worker's skills. The exclusion of wonen allows me to ignore the difticult issues introduced by the fact that women who are out of the labor force do not report an occupation. I also focus on workers aged 251064 so that the obsened occupational earnings are not contaminated by the occupational "shopping" that takes place among younger workers. of by the occupational shifts that occur as nen approach the end of theif carecrs.
} 
TABLE 2

SUMMARY CHARACTERISTICS OF NATIVES AND IMMIGRANTS IN 1910 CENSUS

\begin{tabular}{|c|c|c|c|c|c|c|}
\hline \multirow[b]{2}{*}{ Varlable: } & \multicolumn{2}{|c|}{ White Natives } & \multicolumn{2}{|c|}{ Impigrants } & \multicolumn{2}{|c|}{$\begin{array}{c}1900-1910 \\
\text { Immigrant Wave } \\
\end{array}$} \\
\hline & Al1 & $\begin{array}{c}\text { Non- } \\
\text { Agriculture }\end{array}$ & Al1 & $\begin{array}{c}\text { Non- } \\
\text { Agriculture }\end{array}$ & A11 & $\begin{array}{c}\text { Non- } \\
\text { Agrifulture }\end{array}$ \\
\hline $\begin{array}{l}\text { Age } \\
x \text { L1terate } \\
\log \text { (Wage) }\end{array}$ & $\begin{array}{r}39.8 \\
95.8 \\
6.409\end{array}$ & $\begin{array}{r}39.0 \\
98.2 \\
6.535\end{array}$ & $\begin{array}{r}40.1 \\
86.9 \\
6.321\end{array}$ & $\begin{array}{r}39.4 \\
86.6 \\
6.378\end{array}$ & $\begin{array}{r}33.5 \\
77.1 \\
6.212\end{array}$ & $\begin{array}{r}33.3 \\
77.4 \\
6.264\end{array}$ \\
\hline $\begin{array}{l}\text { x Residing: } \\
\text { in Large Cities } \\
\text { in Northeast } \\
\text { in North-Central } \\
\text { In South }\end{array}$ & $\begin{array}{l}28.1 \\
25.7 \\
35.2 \\
29.6\end{array}$ & $\begin{array}{l}43.8 \\
33.7 \\
34.3 \\
21.7\end{array}$ & $\begin{array}{r}53.7 \\
47.2 \\
34.3 \\
4.4\end{array}$ & $\begin{array}{r}63.4 \\
53.7 \\
30.7 \\
4.4\end{array}$ & $\begin{array}{r}54.0 \\
52.6 \\
28.4 \\
4.6\end{array}$ & $\begin{array}{r}59.8 \\
56.6 \\
28.4 \\
4.1\end{array}$ \\
\hline $\begin{array}{l}\text { * Employed in: } \\
\text { Agriculture } \\
\text { Mining } \\
\text { Manufacturing } \\
\text { Transportation } \\
\text { Trade } \\
\text { Public Adm. } \\
\text { Professions } \\
\text { Domestic Serv. } \\
\text { Clerical }\end{array}$ & $\begin{array}{r}36.9 \\
2.2 \\
26.4 \\
8.5 \\
12.3 \\
2.0 \\
4.5 \\
3.5 \\
3.7\end{array}$ & $\begin{array}{l}\ldots . \\
\cdots \\
\cdots \\
\cdots \\
\cdots \\
\cdots \\
\cdots \\
\cdots \\
\cdots\end{array}$ & $\begin{array}{r}16.7 \\
6.6 \\
44.3 \\
10.2 \\
10.7 \\
1.7 \\
2.2 \\
6.0 \\
1.7\end{array}$ & $\begin{array}{l}\cdots \\
\cdots \\
\cdots \\
\cdots \\
\cdots \\
\cdots \\
\cdots \\
\cdots \\
\cdots\end{array}$ & $\begin{array}{r}10.6 \\
10.0 \\
50.8 \\
12.7 \\
7.1 \\
.8 \\
1.6 \\
5.4 \\
.9\end{array}$ & $\begin{array}{l}\cdots \\
\cdots \\
\cdots \\
\cdots \\
\cdots \\
\cdots \\
\cdots \\
\cdots\end{array}$ \\
\hline $\begin{array}{c}x \text { Employed as } \\
\text { Laborers }\end{array}$ & 14.1 & 10.6 & 24.0 & 24.0 & 37.4 & 36.2 \\
\hline $\begin{array}{l}x \text { of Immigrants } \\
\text { Arriving in: } \\
1900-1910 \\
1890-1899 \\
1880-1889 \\
1870-1879 \\
\text { Prior to } 1870\end{array}$ & $\begin{array}{l}\cdots \\
\cdots \\
\cdots \\
\cdots\end{array}$ & $\begin{array}{l}\cdots \\
\cdots \\
\cdots \\
\cdots\end{array}$ & $\begin{array}{r}37.7 \\
21.5 \\
26.1 \\
8.9 \\
5.8\end{array}$ & $\begin{array}{r}40.4 \\
21.8 \\
25.1 \\
7.8 \\
4.8\end{array}$ & $\begin{array}{l}\cdots \\
\cdots \\
\cdots \\
\cdots \\
\cdots\end{array}$ & $\begin{array}{l}\cdots \\
\cdots \\
\cdots \\
\cdots\end{array}$ \\
\hline Sample Size & 54,324 & 34,303 & 20,143 & 16,783 & 7,592 & 6,784 \\
\hline $\begin{array}{l}\text { Sample Size } \\
\text { for Wage Data }\end{array}$ & 39,803 & 34,126 & 18,241 & 16.741 & 7,510 & 6.775 \\
\hline
\end{tabular}


To obtain a summary measure of immigrant and native skills, I constructed a wage series based on the detailed occupational categories available in the 1910 Census and the 1900 occupational wage structure calculated by Preston and Haines (1991). For the most part, the Preston-Haines occupational wage data is based on the 1901 cost-of-living survey conducted by the U.S. Commissioner of Labor.

The occupational codes reported in the 1910 Census were essentially a combination of industry/occupational breakdowns (for a total of 420 categories). For example, laborers employed in chemical industries are differentiated from laborers employed in lumber and furniture industries, who are in tum differentiated from laborers employed by steam railroads. To impute an average wage to each industry/occupation category in the 1910 Census, I first matched the 1910 Census occupation codes to those reported by the 1900 Census. 1 then used the average annual earnings calculated by Preston and Haines for each of the 1900 Census occupation codes to assign each worker in the 1910 Census a mean occupational wage. ${ }^{6}$

This earnings imputation introduces a number of problems. First, the occupational wage structure, as described by the 1901 cost-of-living survey underlying the Preston-Haines data, could have changed substantially by 1910 . Unfortunately, little can be done about this problem since the next survey by the Commissioner of Labor did not occur until 1918, when additional (and perhaps even larger) changes in the occupational wage structure may have taken place. Second, the wage measure given by a worker's "occupational earnings" obviously ignores the sizable intra-occupation skill differentials that exist in the population. Finally, because the income of many agricultural workers, particularly those who owned their own farms, depended on such

\footnotetext{
${ }^{6}$ I was able to successfully match the occupations of workers in the 1910 census 10 the 1900 codes for 99 percent of the workers in my sample.
} 
unobservable factors as farm and harvest size, Preston and Haines did not impute an income to the occupation of "farmers", who make up a relatively large fraction of persons employed in the agricultural industry. This problem is particularly acute for native workers, because nearly 40 percent of them worked in agriculture (and 60 percent of these natives were classified as farmers).

The large number of observations with missing wage data is evident in Table 2, which shows that only 39,803 white native men (out of a sample of 54,324 workers) were assigned an occupational wage. Because few immigrants are employed in agriculture, however, there are fewer missing observations in the calculation of average earnings in the immigrant population; out of a sample of 20,143 working immigrants, 18,241 were assigned an occupational wage. The missing data problem, in fact, is not significant for any of the national origin groups making up the immigrant population.

Table 2 reports that among workers employed outside agriculture, immigrants earned about 15 percent less than natives. ${ }^{7}$ The wage disadvantage increased to 25 percent for immigrants who arrived between 1900 and 1910 . The differences between immigrants and natives, however, are dwarfed by the dispersion that existed among national origin groups in the immigrant population. Because even at the peak of the Great Migration relatively few countries were important source of immigration to the United States, only 32 national origin groups comprised 99.5 percent of the immigrant population. Table 3 documents the differences that existed among these groups for the stock of immigrants present in the United States in 1910.8

\footnotetext{
${ }^{7}$ Blau (1980) and Eichengreen and Gemery (1986) provide interesting sludics of the observed eamings differential belween intmigrants and natives at the turn of the century.

${ }^{8}$ Equally targe differences a mong ethnic groups are found if the calculations are restricted 10 the subsintple of imuligranls who artived belween 1900 and 1910.
} 
TABLE 3

SUMMARY CHARACTERISTICS OF IMMIGRANTS IN 1910 CENSUS, BY NATIONAL ORIGIN

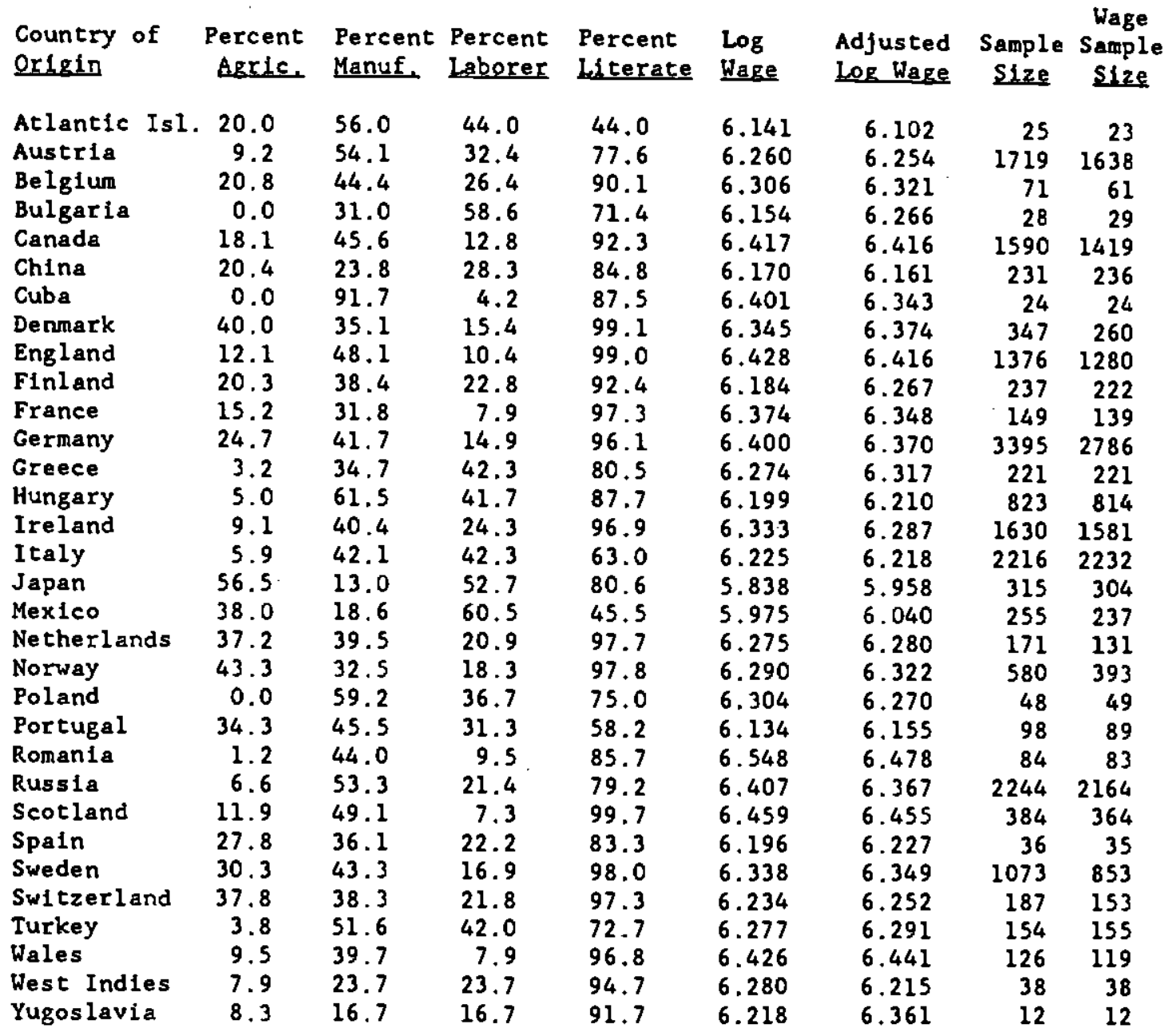

Note: The adjusted $\log$ wage is based on a regression estimated in the sample of immigrants in the 1910 Census. The explanatory variables included age, age squared, a vector of region dumies, and a dumny indicating if the imigrant resided in a metropolitan area, as well as ethnic fixed effects. The adjusted $\log$ wages are evaluated at the mean value of the explanatory variables in the immigrant sample. 
There exist huge skill differences among groups. The fraction of immigrants who knew how to read and write any language was 45.5 percent for Mexican immigrants, 75.0 percent for Polish immigrants, and 99.0 percent for English immigrants. The implied wage differentials are equally large: Mexican immigrants earn about 15 percent less than Portuguese immigrants, who in turn earn about 30 percent less than English immigrants.

The ethnic wage differentials remain even after controlling for differences in the age and residential location of the various immigrant groups. To construct these adjusted wages, I estimated a regression of the form:

$$
\log w_{i j}=X_{i j} \alpha_{1}+d_{j 1}+\varepsilon_{i j}
$$

where $w_{i j}$ is the wage of person $i$ in national origin group $j: X$ is a vector of socioeconomic characteristics defined to have zero mean; and $d_{i n}$ is the fixed effect of type-j first-generation Americans (evaluated at the mean level of the $X^{\prime} \mathrm{s}$ ). The standardizing variables include age (and age squared), a vector of dummies indicating region of residence, and a dummy indicating if the person lives in a metropolitan area.

Table 3 also reports the adjusted log wages. Immigrants who originated in England earn about 13 percent more than "similar" immigrants who originated in Ireland, who in turn earn about 25 percent more than those from Mexico. The wage differentials among the national origin groups that made up the Great Migration, therefore, are sizable and remain even after controlling for differences in their age distribution and spatial location. 


\section{Ethnic Skill Differentinls in the 1940 and 1980 Censuses}

Although Census data do not generally identify the skills of parents (except for the small subsample of persons who still reside with their parents), well-designed intercensal comparisons of first- and second-generation workers can be used to analyze the extent of intergenerational mobility. To determine if the skill differentials that characterized the original national origin groups persisted among their children, I use the 1/100 1940 Public Use Sample to identify the economic status of the various ethnic groups in the second generation.

I restrict the analysis of the data to second-generation men aged 25-64, who worked in the civilian sector in the year prior to the Census, and who were not enrolled in school. A person is classified to be a second-generation American if either parent was born outside the United States. The ethnic group of the second-generation worker is defined in terms of the father's birthplace (unless only the mother was foreign-born, in which case it is defined in terms of the mother's birthplace). The analysis is further restricted to second-generation workers who can be classified into one of the 32 national origin groups that made up the bulk of the Great Migration. These workers comprise 98.3 percent of all second-generation workers in 1940 .

The analysis focuses on the educational attainment and log wage of second-generation workers. I use two alternative measures of the wage: the reported log hourly wage of the worker in the year prior to the Census (i.e., the ratio of annual earnings in 1939 to annual hours worked), and an occupational wage created by assigning each worker the mean log wage rate in his three-

\footnotetext{
9 Thic intercensal linkage beiween parents and children can be improved in a numiber of ways. For c.vaniple. He children of imnigrants aged $25-4+$ in 1910 are likely to be relatively young in 19-10. While the children of intmigrants aged $+5-6+$ in 1910 are likely 10 be relatively older in $19+0$. I experimented with a nutuber of alternative age breakdowns. and generally obtalned the same quantitative results. I also conducted calculations whicl defined a person as second-generation only if both parents werc bom outside the United States. The results were not sensitive to the definition of the second gencration.
} 
digit occupation. The use of the occupational wage is designed to maintain comparability with the wage measure available in the 1910 Census.

The first five columns of Table 4 summarize the 1940 data. There are substantial differences in schooling and wages among second-generation ethnic groups. For instance, second-generation workers whose parents originated in England or Austria have 2.5 more years of schooling than those originating in Portugal, and 5 more years than those originating in Mexico. Similarly, the occupational wage of second-generation English workers is about 10 percent higher than that of German workers, and about 30 percent higher than that of Portuguese workers. Finally, to determine if these wage differentials could be explained by individual differences in age or residential location, I estimated an equation analogous to (1) in the 1940 Census data. As Table 4 shows, there is substantial dispersion in adjusted wage rates across ethnic groups in 1940, even in terms of the occupational wage.

The link between the skill differentials in the first and second generations is illustrated in Figures 1 and 2. In particular, Figure 1 shows the link between the educational attainment of 1940 second-generation ethnic groups and the literacy rate of the corresponding first-generation national origin group in 1910, while Figure 2 illustrates the link between the occupational wage of second-generation ethnic groups in 1940 and the corresponding immigrant group in 1910. The data points in Figures $I$ and 2 are drawn from measures of literacy, education, and wages that are adjusted for differences in age, region, and metropolitan residence among groups (i.e., a regression analogous to (1) was estimated for each of the variables in each Census). It is evident that there is a strong positive relationship between the skills of immigrants and the skills of corresponding second-generation ethnic groups. 
TABLE 4

SUMMARY CHARACTERISTICS OF SECONO GEMERATION IH 1940 AMO MTHIRO GENERATIOHM IK 1980

\begin{tabular}{|c|c|c|c|c|c|c|c|c|c|c|}
\hline \multirow[b]{3}{*}{$\begin{array}{l}\text { Country of } \\
\text { Origin }\end{array}$} & \multicolumn{5}{|c|}{1940 Census } & \multicolumn{5}{|c|}{1980 Census } \\
\hline & & \multirow{2}{*}{$\begin{array}{l}\text { Reported } \\
\text { Log } \\
n \quad \text { Hege }\end{array}$} & \multicolumn{2}{|c|}{ Occupational } & \multirow[b]{2}{*}{$\begin{array}{l}\text { Sample } \\
\text { size }\end{array}$} & \multirow{2}{*}{ Education } & \multirow{2}{*}{$\begin{array}{l}\text { Reported } \\
\text { Log } \\
\text { Wage }\end{array}$} & \multicolumn{2}{|c|}{ Occupstionsl } & \multirow{2}{*}{$\begin{array}{l}\text { Sample } \\
\text { size }\end{array}$} \\
\hline & Education & & $\begin{array}{l}\text { log } \\
\text { Wage }\end{array}$ & $\begin{array}{l}\text { Ad justed } \\
\text { Log Wage }\end{array}$ & & & & $\begin{array}{l}\text { Log } \\
\text { Yage }\end{array}$ & $\begin{array}{l}\text { Adjusted } \\
\text { Log Woge }\end{array}$ & \\
\hline Atlentic IsI. & . 8.3 & -0.395 & -0.579 & -0.564 & 12 & 13.1 & 1.867 & 1.978 & 1.989 & 17 \\
\hline Austris & 10.1 & -0.328 & -0.414 & -0.434 & 376 & 16.5 & 2.282 & 2.141 & 2.140 & 1094 \\
\hline Belgium & 9.2 & -0.453 & -0.523 & -0.516 & 31 & 13.2 & 2.152 & 2.073 & 2.076 & 382 \\
\hline Bulgaría & 13.0 & -1.204 & -0.087 & -0.119 & 2 & 13.2 & 2.097 & 2.085 & 2.080 & 56 \\
\hline Canada & 9.8 & -0.492 & -0.467 & -0.444 & 928 & 12.7 & 2.060 & 2.046 & 2.040 & 1607 \\
\hline China & 6.0 & -1.101 & -0.912 & -0.935 & 21 & 14.9 & 2.153 & 2.111 & 2.090 & 424 \\
\hline cubs & 9.7 & -0.722 & -0.442 & .0 .516 & 11 & 13.2 & 1.937 & 2.050 & 2.041 & 84 \\
\hline Dermark & 9.8 & -0.542 & -0.528 & -0.464 & 169 & 13.8 & 2.163 & 2.090 & 2.093 & 1618 \\
\hline Engl and & 10.2 & -0.287 & -0.400 & $=0.409$ & 860 & 13.0 & 2.076 & 2.066 & 2.068 & 66405 \\
\hline finl and & 9.2 & -0.522 & .0 .559 & $.0 .4 B O$ & $\infty$ & 13.5 & 2.134 & 2.074 & 2.083 & 782 \\
\hline france & 9.9 & -0.377 & -0.395 & -0.394 & 142 & 12.6 & 2.047 & 2.048 & 2.046 & 12139 \\
\hline Germany & 9.2 & -0.410 & -0.493 & -0.489 & 2590 & 13.1 & 2.099 & 2.062 & 2.065 & 60877 \\
\hline Greece & 9.9 & -0.657 & -0.496 & -0.508 & 29 & 14.0 & 2.177 & 2.009 & 2.092 & 1068 \\
\hline Hungary & 10.1 & -0.309 & -0.452 & -0.489 & 154 & 13.4 & 2.167 & 2.079 & 2.076 & 2090 \\
\hline Irel and & 9.8 & -0.315 & -0.431 & -0.458 & 1265 & 13.0 & 2.084 & 2.060 & 2.059 & 33796 \\
\hline Italy & 9.1 & -0.506 & .0 .503 & -0.521 & 975 & 13.0 & 2.140 & 2.065 & 2.059 & 16520 \\
\hline Japan & 11.5 & -1.004 & -0.518 & -0.503 & 4 & 13.9 & 2.142 & 2.063 & 2.057 & 1050 \\
\hline Mexico & 5.0 & -1.297 & -1.067 & -0.995 & 121 & 10.7 & 1.895 & 1.941 & 1.928 & 7139 \\
\hline Metherl ands & 9.6 & -0.563 & -0.528 & -0.479 & 111 & 12.7 & 2.050 & 2.046 & 2.049 & 5817 \\
\hline Morway & 10.0 & -0.529 & -0.561 & $-0,488$ & 360 & 13.5 & 2.096 & 2.061 & 2.068 & 4193 \\
\hline Poland & 8.9 & .0 .466 & -0.499 & .0 .523 & 852 & 13.1 & 2.145 & 2.067 & 2.065 & 11197 \\
\hline Portugal & 7.6 & -0.606 & -0.705 & -0.666 & 41 & 12.2 & 2.046 & 2.010 & 2.000 & 1043 \\
\hline Romania & 11.6 & -0.496 & -0.363 & -0.391 & 43 & 14.6 & 2.266 & 2.128 & 2.121 & 356 \\
\hline Russía & 11.2 & -0.347 & .0 .354 & .0 .378 & 669 & 15.4 & 2.313 & 2.163 & 2.154 & 3519 \\
\hline Scot land & 10.2 & -0.305 & $-0,439$ & -0.446 & 269 & 13.9 & 2.142 & 2.103 & 2.102 & 11223 \\
\hline Spaín & 9.2 & .0 .424 & -0.352 & -0.388 & 22 & 11.9 & 1.888 & 2.006 & 1.093 & 87 \\
\hline sweden & 10.1 & -0.389 & -0.486 & -0.451 & 652 & 13.7 & 2.148 & 2.085 & 2.088 & 4885 \\
\hline swi tzer land & 10.3 & -0.307 & -0.436 & -0.430 & 118 & 14.0 & 2.128 & 2.100 & 2.105 & 1037 \\
\hline Turkey & 11.3 & -0.340 & -0.456 & -0.468 & 10 & 14.2 & 2.166 & 2.163 & 2.160 & 33 \\
\hline wales & 10.0 & -0.217 & -0.391 & -0.382 & 73 & 14.1 & 2.137 & 2.084 & 2.083 & 1873 \\
\hline West Indies & 9.3 & -0.631 & -0.611 & -0.754 & 4 & 12.2 & 1.837 & 2.002 & 1.992 & 36 \\
\hline Yugosiavia & 8.9 & -0.316 & -0.501 & -0.495 & 67 & 13.4 & 2.243 & 2.088 & 2.085 & 1061 \\
\hline
\end{tabular}

Note: The adjusted log wages are based on regressions estimated separately in the sample of second-generation workers in 1940 and third-generation workers in 1980. The explanatory variables included age, age squared, a vector of region dumies, and a dummy indicating if the immigrant resided in a metropolitan ares, as well as ethnic fixed effects. The 1940 adjusted log ages are evaluated at the mean value of the explanatory variables in the second-generation sample, while the 1980 adjusted log wages are evaluated at the mean value of the explanstory variables in the third-generation sample. 


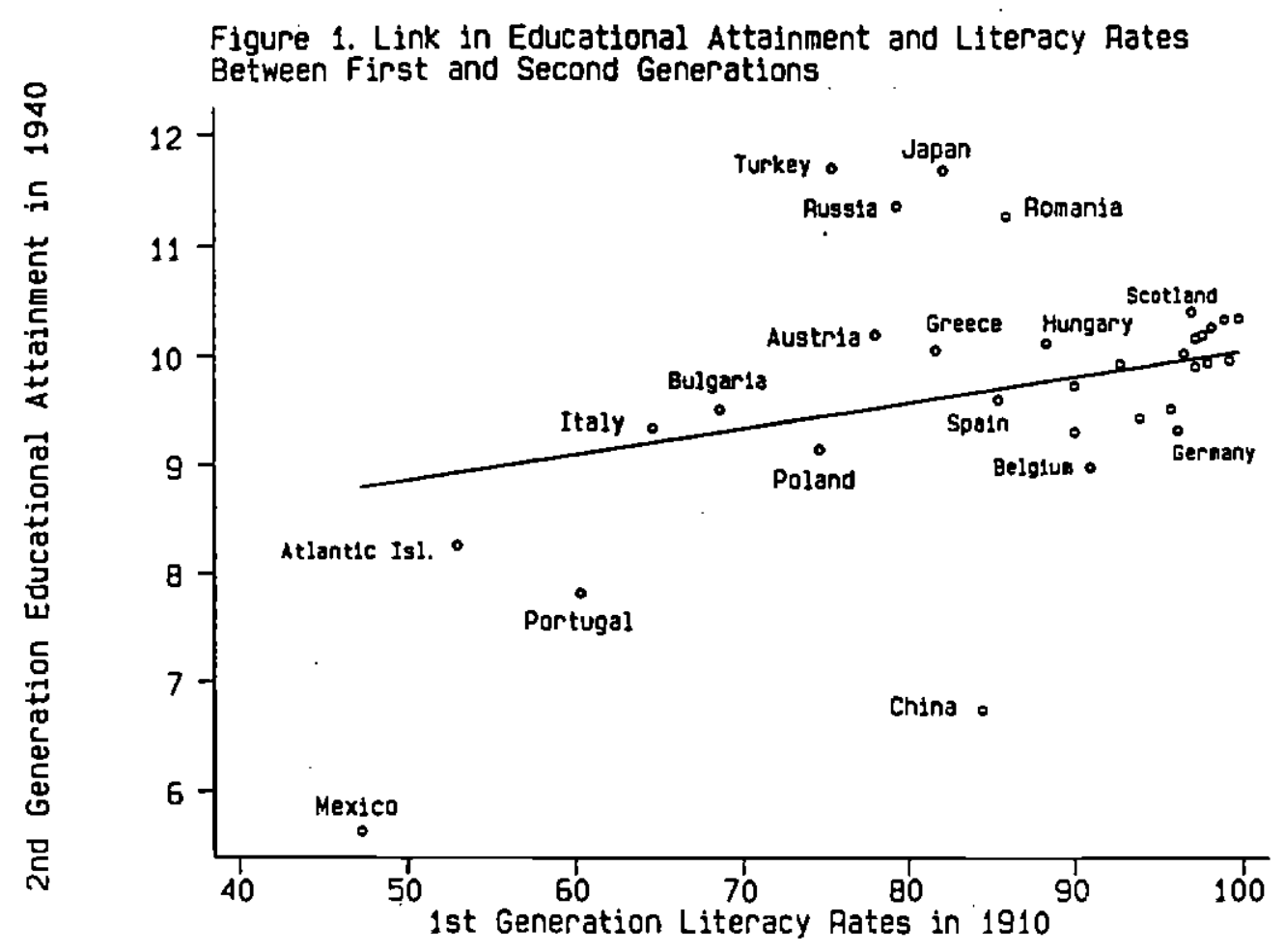


Figure 2. Link in Wages Between First and Second Generations

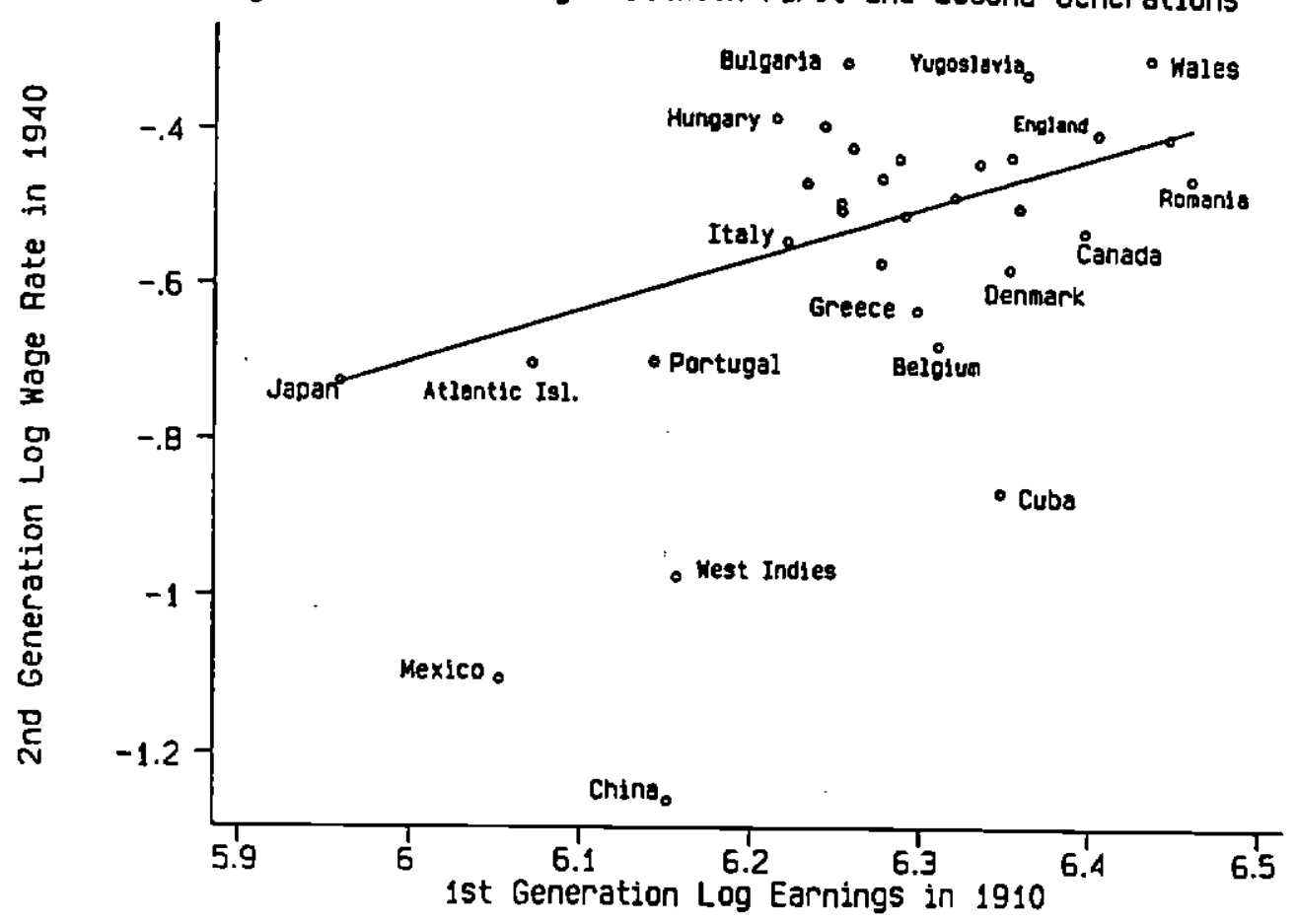


To determine the intensity of this link, I estimated regressions of the form:

(2)

$$
y_{i j 2}=X_{i j} \alpha_{2}+\gamma d_{i 1}+\varepsilon_{i 2,}
$$

where $y_{i j 2}$ measures the skills of person $i$ in ethnic group $j$ in the second generation; $X_{i j}$ is a vector of standardizing characteristics defined to have mean zero; and $d_{j 1}$ is the measure of average skills for type-j immigrants (obtained from the estimation of equation (1) in the 1910 first-generation sample). As before, the standardizing vector $X_{i j}$ includes age (and age squared), a vector of region dummies, and a dummy variable indicating if the individual lived in a metropolitan residence. The coefficient $\gamma$ is the intergenerational transmission coefficient, or a rough measure of the "intergenerational correlation."

It is useful to provide an alternative interpretation of the regression model in (2). An ethnic fixed effect can be estimated among second-generation workers in the 1940 Census using the specification:

$$
y_{i 22}=X_{i j} \alpha+d_{j 2}+\varphi_{i j}
$$

Because the variables in the vector $X$ are defined to have mean zero, the fixed effect $d_{j 2}$ gives the adjusted skills of the ethnic group. The extent to which the average skills of second-generation type-j workers are related to the average skills of their parents is summarized by:

$$
d_{j 2}=\mu+\beta d_{j 1}+v_{j}
$$


Substituting (4) into (3) yields the model in (2). Note that the disturbance in (2) equals $\varphi_{i j}+v_{p}$ so that it contains a group-specific error term. Therefore, the model is estimated using a randomeffects estimator. ${ }^{10}$

Table 5 reports the estimated transmission coefficients for a number of alternative specifications of equation (2); the corresponding regression lines linking the ethnic fixed effects in the two generations are illustrated in Figures 1 and 2. The first row relates the 1940 educational attainment of the ethnic group to the literacy rate of the immigrant group in 1910 . It is evident that the second-generation offspring of skilled immigrant groups had more schooling. In particular, a 20 percentage point difference in literacy rates among two immigrant groups in 1910 translated to a difference of about one year of schooling for their children. The summary statistics in Table 3 indicate that differences in literacy rates of 20 percent or more among the groups were not uncommon, so that the linkage between the two generations generates substantial differences in educational attainment among second-generation workers.

The second row of Table 5 relates the occupational wage of the ethnic group in 1940 to the wage of the immigrant group in 1910. The regression also indicates a very strong link between the wages of immigrants and their ethnic children. The intergenerational transmission coefficient is in the order of 6.11

\footnotetext{
1011 is important to note that the random effects estimator roughly weighs cach observation by some estintate of sampling variance. As a result, national origin groups that have few obsenations (as some groups in Tablc + do) contribute relativcly little to the estimation of the intergencrational correlation.

11 The results summarized in Table 5 do not address the question of whether there is more mobility. between inumigrants and their children than between any other two gencrations. Borjas (1993) uscs the $19+0$ and 1970 Censuses 10 analyze the economic improvement, experienced by the children of immigrants present in lle United States in 1940. The data suggest that the mobility between the first and sccond generations exceeds that experienced by the children of second-generation workers.
} 
TABLE 5

IMPACT OF 1910 IMMIGRANT SKILLS ON ETHNIC SKILL DIFFERENTIALS IN 1940

1940 Dependent Variable:

1. Education

2. Occupational Log Wage

3. Occupational Log Wage

4. Reported Log Wage

5. Reported Log Wage
Characteristics of

Immlgrants in 1910

\begin{tabular}{c} 
Literacy $\begin{array}{r}\text { Log } \\
\text { Race }\end{array}$ \\
\hline
\end{tabular}

$5.1176^{*}$

(.9597)

\author{
Controls \\ for 1940 \\ Education $\underline{\mathrm{R}}^{2}$ \\ No $\quad .100$
}

... $.6018^{\star}$

(.1374)

... $.2260^{*}$

(.0872)

... $.6724^{\star}$

(.1942)

... $.2689^{\star}$

(.1516)
No $\quad .081$

Yes $\quad .186$

No $\quad .110$

Yes $\quad .148$

Notes: Standard errors are reported in parentheses. The explanatory

vartables also include age, age squared, a vector of region dumnies, and a dumny indicating if the worker restded in a metropolitan area. The regressions are estimated using a random-effects estimator. The sample size of second-generation workers in 1940 is 11,079 .

* Statistically significant at the 5 percent level in a one-tailed test. 
It is of interest to determine if the link between the wages of second-generation ethnic groups and the skills of immigrants remains after controlling for the education level of secondgeneration workers. To address this issue, I reestimated (2) after expanding the vector $X$ to include educational attainment. The estimated transmission coefficients are reported in the third row of the table. Controlling for education among second-generation workers weakens the link between the first and second generations, but the intergenerational transmission coefficient of .2 is still numerically and statistically significant.

The last two rows of the table replicate the analysis by using the second-generation worker's reported log wage in 1939 (as opposed to the occupational wage) as the dependent variable. The introduction of intra-occupation skill differentials slightly increases the intergenerational transmission coefficients. ${ }^{12}$

To determine the extent to which these ethnic differences are transmitted to still another generation, the grandchildren of the Great Migration immigrants, I initially use the 1980 Census. These data, however, do not provide information on the birthplace of grandparents (and since 1980 the Census does not even provide information on the birthplace of parents). Thus the analysis based on the 1980 Census data contains a substantial amount of measurement error in the measures of third-generation skills. I will show below, however, that the results obtained from the Census data do not change when the study is replicated on a (smaller) data set that provides direct information on the birthplace of grandparents.

In the 1980 Census, individuals were asked to self-report their ancestral group. I use the person's first reported ancestry to classify workers into one of the 32 ethnic groups used in the

12 The $\mathrm{R}^{\text {: }}$ stalistics reported in Table $S$ refer to the explanatory power of the micro-level model in equation (2). The $R^{*}$ of the second-stage regression in equation (4) is generally in the range of .3 to .4. 
analysis. ${ }^{13}$ This matching was possible for nearly 80 percent of non-black natives. Persons who could not be classified into one of the 32 groups were omitted from the analysis. Most of the persons who were omitted either did not report an ancestry (45 percent of the excluded observations), or reported "American" (26 percent). ${ }^{14}$

I again restrict the study to native-born working men aged 25-64, who were employed in the civilian sector in the year prior to the Census, and who were not enrolled in school. An occupational wage is calculated by assigning each worker the 1980 mean log wage in his threedigit occupation, and the reported wage is defined as the ratio of annual earnings to annual hours worked. The last five columns of Table 4 summarize the ethnic skill differentials found in 1980. Although the differentials have narrowed by the "third generation", there still remain significant differences, even among groups of European origin. The educational attainment of persons of Dutch or French ancestry is approximately 12.5 years, while the educational attainment of Austrians or Russians is about 15 years. Similarly, the wage of Irish workers is about 20 percent less than that of Austrian or Russian workers.

Figures 3 and 4 contrast the educational attainment and occupational wage of the ethnic groups in the 1980 Census with the skills of the immigrant groups in the 1910 Census. There is a correlation between the skills of the original immigrant groups and the skills of ethnic groups two generations apart. To determine the intensity of this link, l estimated regressions of the form:

13 The 1980 Census allows persons 10 report two different ancestries (e.g.. German-Irish). My analysis is based on the classification obtained from the first reported ancestry. I experimenicd with aliemative classifications that used the second reported ancestry. These experiments. however. did not alter the resulis because fewer than $t 0$ percent of the observations in my sample reported an additional ancestry.

14 The I980 Census citraci obviously does not provide a random sample of the third-generntion. Because the stibsimple used in the analysis is restricted to persons with the strongest cthnic identin; the probability that the 1980 data is mainly composed of second- and third-gencration Americans is incrensed. 
Figure 3. Link in Educational Attainment and Literacy Rates

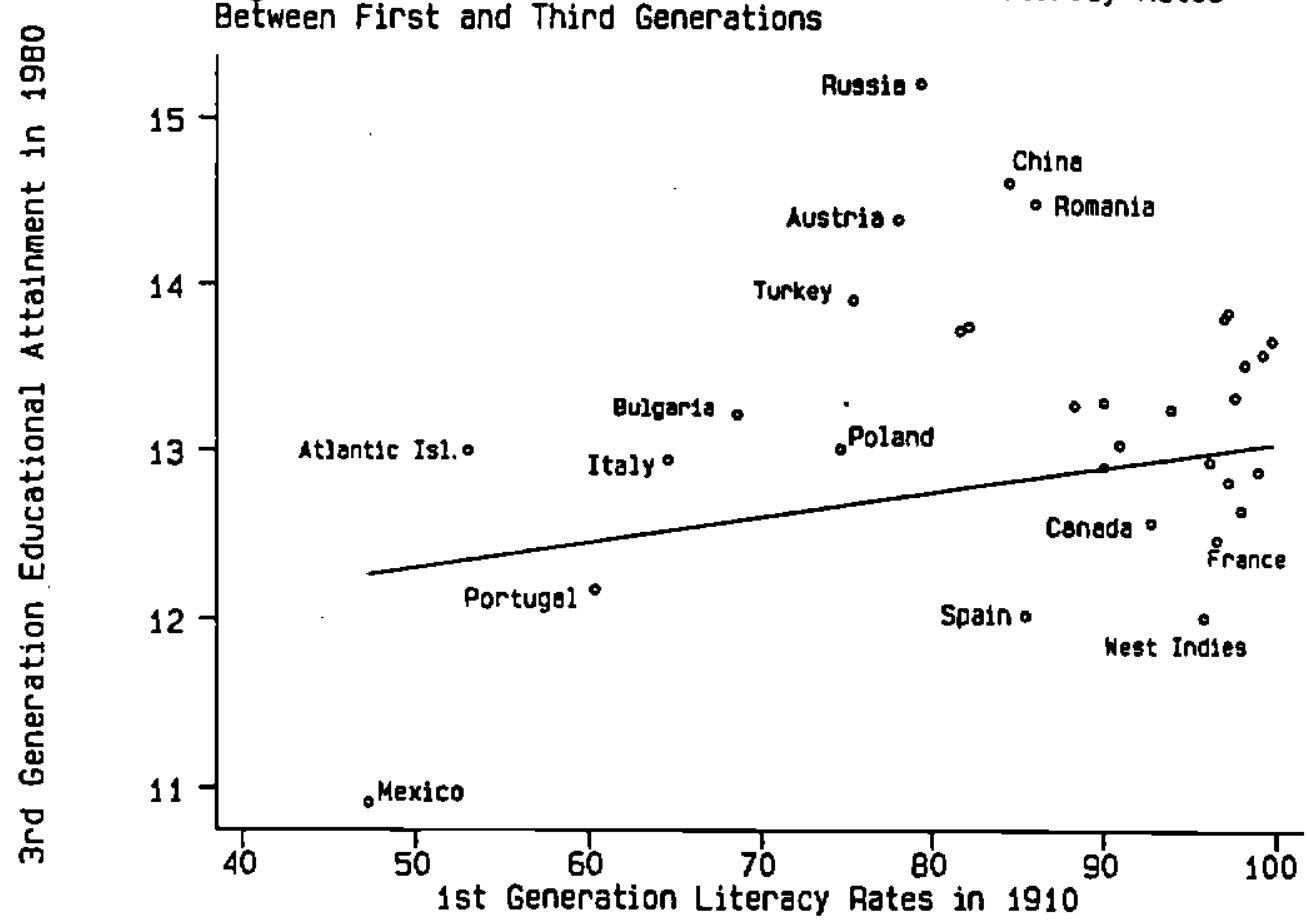


Figure 4. Link in Wages Between First and Third Generations

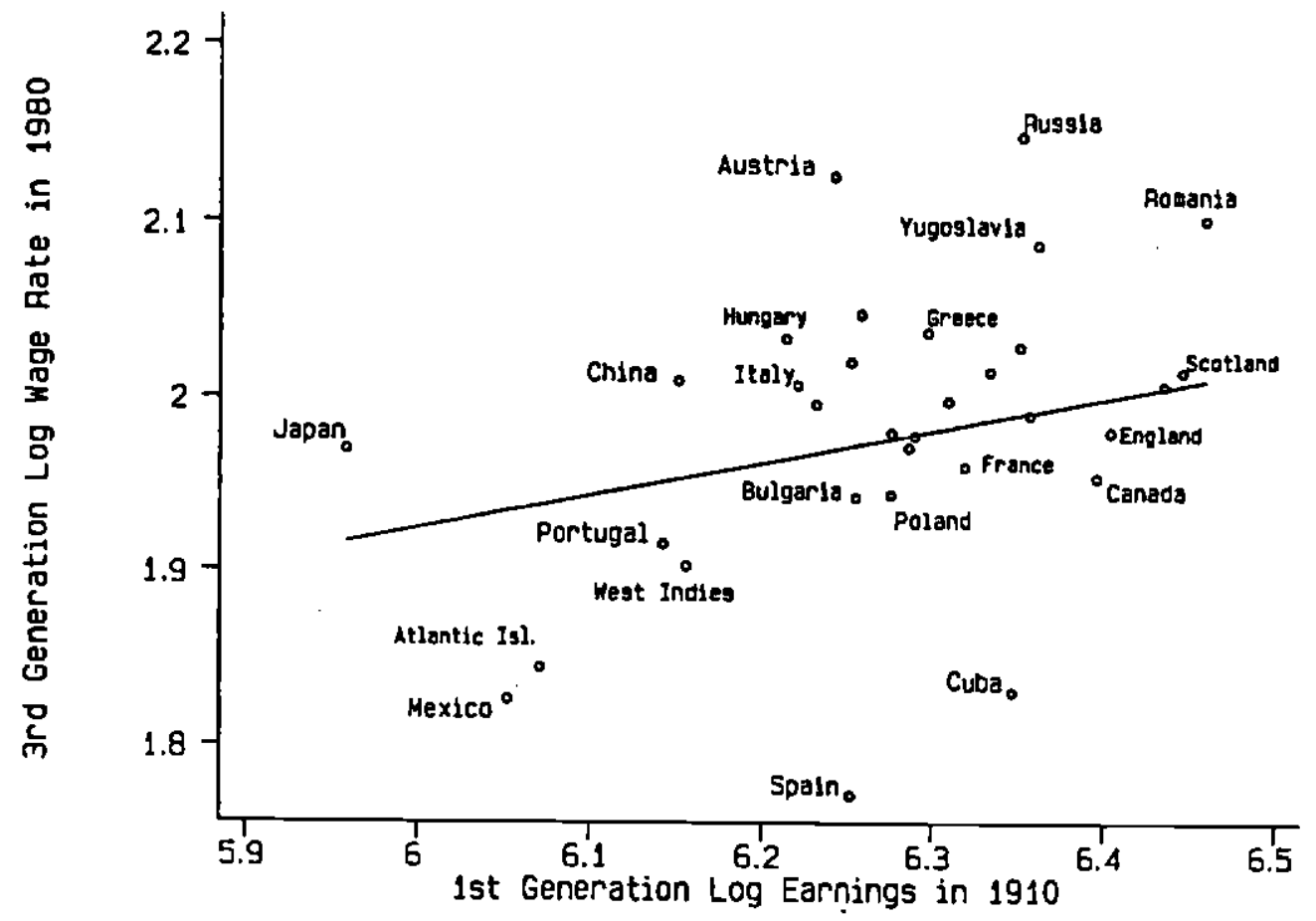




$$
y_{i j 3}=X_{i j} \alpha_{3}+\theta d_{j 1}+\varepsilon_{i j}
$$

where $y_{i j 3}$ measures the skills of "third-generation" workers in the 1980 Census. If the intergenerational transmission parameter in equation (2) is constant across generations, the parameter $\theta$ should be equal to $\beta^{2}$. Table 6 presents the key results obtained from alternative specifications of equation (5).

The first row reports a strong correlation between the educational attainment of ethnic groups in 1980 and the literacy rates of the immigrant groups during the Great Migration. A 20 percentage point differential among immigrants in 1910 leads to a .5 year difference in educational attainment among their "grandchildren". Note that this statistic is half the size of the impact of the 1910 literacy rate on the educational attainment of second-generation workers in 1940. Because the 1940 and 1980 Censuses provide data on years of schooling while the 1910 Census reports the literacy rate of the immigrant grandparents, the regression coefficients in the first row of Tables 5 and 6 cannot be interpreted as an intergenerational correlation in educational attainment. If the relationship between literacy and years of schooling in the immigrant generation is linear, however, the ratio of the coefficients in Tables 5 and 6 estimates the intergenerational correlation between the second and third generations. 1s The implied correlation is .47.

is Lel $y_{j 1}$ be the (unobser'ed) educational attainment of group $j$ in the immigrant generalion. The observed dala on literacy rales is given by the variable $\mathrm{r}_{\mathrm{jl}}$. Suppose that the relationslip between these lwo skill meisures can be wrilten as:

$$
v_{j 1}=\bar{\kappa} r_{j 1}+\eta_{j} .
$$

The equatious that can be estimated are:

$$
v_{i j 2}=f_{i j} \alpha_{2}+\$ \delta r_{j 1}+\varepsilon_{i j 2},
$$


TABLE 6

IMPACT OF 1910 IMMIGRANT SKILLS ON ETHNIC SKILL DIFFERENTIALS IN 1980

\begin{tabular}{|c|c|c|c|c|}
\hline \multicolumn{5}{|c|}{$\begin{array}{l}\text { Characteristics of } \\
\text { Immigrants in } 1910\end{array}$} \\
\hline $\begin{array}{l}1980 \text { Dependent } \\
\text { Varlable: }\end{array}$ & $\begin{array}{c}\text { Literacy } \\
\text { Race }\end{array}$ & $\begin{array}{r}\text { Log } \\
\text { Wage }\end{array}$ & $\begin{array}{l}\text { Controls } \\
\text { for } 1980 \\
\text { Education }\end{array}$ & $\underline{R}^{2}$ \\
\hline 1. Education & $\begin{array}{l}2.4202^{\star} \\
(.7926)\end{array}$ & $\cdots$ & No & .086 \\
\hline $\begin{array}{l}\text { 2. Occupational } \\
\text { Log Wage }\end{array}$ & $\cdots$ & $\begin{array}{l}.2006^{*} \\
(.0469)\end{array}$ & No & .028 \\
\hline $\begin{array}{l}\text { 3. Occupational } \\
\text { Log Wage }\end{array}$ & $\cdots$ & $\left(.0686^{*}\right.$ & Yes & .183 \\
\hline $\begin{array}{l}\text { 4. Reported } \\
\text { Log Wage }\end{array}$ & $\cdots$ & $\left(.0884^{*}\right.$ & No & .080 \\
\hline $\begin{array}{l}\text { 5. Reported } \\
\text { Log Wage }\end{array}$ & $\cdots$ & $\begin{array}{l}.0673 \\
(.0442)\end{array}$ & Yes & .135 \\
\hline
\end{tabular}

\footnotetext{
Notes: Standard errors are reported in parentheses. The explanatory varlables also include age, age squared, a vector of region dummies, and a dumny Indicating if the worker resided in a metropolitan area. The regressions are estimated using a random-effects estimator. The sample size of third-generation workers in 1980 is 251.658 .

*Statistically significant at the 5 percent level in a one-talled test.
} 
The remaining rows of Table 6 also indicate that the relative wage of an immigrant group in 1910 has a strong effect on the relative wage of the corresponding third-generation ethnic group in 1980. In particular, the estimated transmission coefficient is approximately .2 to 3 (depending on whether the dependent variable is the 1980 occupational wage or the reported wage). The correlation decreases to about .07 when the educational attainment of the third generation is held constant.

Table 6 thus reveals that the ethnic skill differentials introduced by the Great Migration have persisted until at least 1980 . The wage regressions, however, suggest that the parameter $\theta$ is less than $\beta^{2}$. Table 5 estimates $\beta$ to be between .6 to .7 , while Table 6 estimates $\theta$ to be between .2 and .3 . The results thus raise the possibility that the intergenerational transmission coefficient is not constant across generations, but gets weaker the longer the ethnic group resides in the United States. The estimated parameters, however, have large standard errors, and I cannot reject the hypothesis that $\beta^{2}=\theta$. The $t$-statistic associated with this test equals .72 , well below conventional significance levels (where the t-statistic was calculating using the "delta method").

As a result, the smaller point estimate of the intergenerational correlations estimated from 1980 wage data may be simply due to the misdefinition of the sample of "third-generation" workers.

\section{Ethuic Capital and Convergence}

$$
v_{i j 3}=x_{i j} \alpha_{3}+\theta \delta r_{j 1}+\varepsilon_{i \beta},
$$

The ratio of the cocficients on the 1910 literacy mate identifies $\theta / \beta$. If $\theta=\beta^{2}$. the ratio is then equal to $\beta$. If the intcrgencrational correlation changes across generations so that $\tau$ is the correlation between the second and third generntions then $\theta=\beta \tau$. and the ratio of coefficients identifies the correlation between the sccond and lhird generations or $\tau$. 
The analysis of decennial Census data from 1910 to 1980 reveals that the ethnic skill differentials created by the Great Migration did not converge within three generations, and that it may take at least one more generation for these differences to disappear from the American economy. I now show that the key reason for the slow convergence is the role played by ethnicity itself in the intergenerational transmission of skills.

In recent work (Borjas, 1992), I have argued that ethnicity acts as an externality in the human capital accumulation process. In particular, the skills of the next generation depend not only on parental inputs, but also on the average quality of the ethnic environment in which parents make their investments, or "ethnic capital". ${ }^{16}$ Persons who grow up in advantageous ethnic environments will, on average, be exposed to social, cultural, and economic factors that increase their productivity when they grow up, while persons who grow up in a disadvantaged ethnic milieu are likely to be adversely affected by this exposure. It is easy to show that if this ethnic spillover is sufficiently strong, skill differentials observed among immigrant groups can persist for many generations. The simplest version of the ethnic capital model suggests that the intergenerational transmission process can be described by:

$$
y_{i j}(t)=\beta_{1} y_{i j}(t-1)+\beta_{2} \bar{y}_{j}(t-1)+\varepsilon_{i j}(t),
$$

where $y_{i j}(t)$ gives the skill level of person $i$ in ethnic group $\mathrm{j}$ in generation $\mathrm{t}$, and $\bar{y}_{1}(t-1)$ gives the average skill level of the ethnic group in generation $\mathrm{t}-1$.

\footnotetext{
16 The chnic capilal wodel is closely related to the growing literature that sludics lhe rate of convergence in per capila income (or oulput) across countries. Insightful discussions of thesc "new" growth models are given by Lucas (1983) and Romer (1986).
} 
The hypothesis that ethnicity has spillover effects on human capital accumulation has been widely used in the sociology literature. For instance, Coleman (1988) stresses that the culture in which the individual is raised (which he calls "social capital") is a form of human capital common to all members of that group. He argues that social capital alters the opportunity set of workers and has significant effects on behavior, human capital formation, and labor market outcomes. Similarly, in his influential study of the underclass, Wilson (1986) argues that the presence of mainstream role models in poor neighborhoods serves an important social and economic function.

It is easy to show the link between the ethnic capital model in (6) and the intergenerational transmission coefficients estimated using the aggregate Census data in the previous section. Aggregating equation (6) within ethnic groups leads to:

$$
\bar{y}_{j}(t)=\left(\beta_{1}+\beta_{2}\right) \bar{y}_{j}(t-1)+\bar{\varepsilon}_{j}(t)
$$

The regressions estimated in aggregate Census data, therefore, estimate $\beta_{1}+\beta_{2}$. This sum yields precisely the intergenerational transmission coefficient relevant for determining the rate at which the mean skills of ethnic groups converge across generations, or "mean-convergence".17

To document the importance of ethnic capital in delaying the disappearance of the ethnic differentials introduced by the Great Migration, I use data drawn from the General Social Surveys, a series of annual cross-sections that have been collected since the mid-1970s (Davis and Smith, 1989). The GSS is well-suited for the analysis because it reports if the parents and

\footnotetext{
${ }^{17}$ The intcrgencrational transmission coefficients estimated in aggregatc Census data are known in the sociological litcrature as "ecological" correlations. For a discussion of alternative concepts of convergence. see Barro and Sala-i-Martin (1992).
} 
grandparents were born outside the United States, as well as provides information on ethnicity and parental education and occupation. The empirical analysis pools persons aged 18-64 from the 1977-1989 cross-sections and focuses on the study of intergenerational mobility in educational attainment and earnings. The earnings of both the father and of the GSS respondent are obtained by matching the 1970 Census occupation codes reported in the GSS to mean earnings in the occupation as reported by the 1970 Census.

The ethnicity question in the GSS resembles the ancestry question in the 1980 Census. Although most persons in the sample gave only one ancestral background, some gave multiple responses. I then use the main ethnic background (as identified by the respondent) to classify the GSS respondents into the 32 ethnic groups that made up the bulk of the Great Migration. Persons who have missing data on the ethnicity question, who cannot be classified into one of the 32 groups, or who have missing data on the other variables used in the analysis are omitted from the study. Finally, the analysis is restricted to the GSS respondents who had at least one foreignborn grandparent, so that the GSS results focus specifically on third-generation Americans. ${ }^{18}$ Equation (7) relates the skills of generation $t$ (the GSS respondents) to those of their parents. The equation relating the skills of the parents to those of the immigrant grandparents is:

$$
y_{i j}(t-1)=\theta_{1} y_{i j}(t-2)+\theta_{2} \bar{y}_{j}(t-2)+\varepsilon_{i j}(t-1) \text {. }
$$

\footnotetext{
${ }^{18}$ I conducted sonie calculations to determine if the results changed appreciably when the sample of third-generation Aniericans contained only persons who had either two or four grandparents born outside the United States. Although the estimates of the model had larger standard errors. the qualinative nature of the results did nol change.
} 
where I allow for the intergenerational transmission coefficients to differ across generations. Aggregating (8) within ethnic groups and substituting in (6) yields:

$$
y_{i j}(t-1)=\beta_{1} y_{i j}(t-1)+\beta_{2}\left(\theta_{1}+\theta_{2}\right) \bar{y}_{j}(t-2)+v_{b}(t),
$$

which relates the skills of third-generation Americans to the skills of their parents and to the mean skills of the ethnic group in the grandparent's generation (obtained from the 1910 Census). Note that the rate of mean-convergence between the first and second generations is given by $\beta_{1}+\beta_{2}$ while the rate of mean-convergence between the second and the third is given by $\theta_{1}+\theta_{2}$. The estimation of equations (6) and (9) identify three parameters: $\beta_{1}, \beta_{2}$, and the sum $\theta_{1}+\theta_{2}$. Although it is not possible to test if the impact of parental or ethnic capital is constant across generations (i.e., $\beta_{1}=\beta_{2}$ and $\theta_{1}=\theta_{2}$ ), it is possible to test if the measure of mean convergence is constant across generations $\left(\beta_{1}+\beta_{2}=\theta_{1}+\theta_{2}\right)$.

Table 7 reports the ethnic differentials in educational attainment and earnings observed both among GSS respondents and among their fathers. It is evident that ethnic differences exist not only among ethnic groups in the second-generation (i.e., the parents of GSS respondents), but also among ethnic groups in the third. For instance, the educational attainment of persons whose grandparents originated in Austria and England is about 3 years higher than that of persons of Mexican background, but 1 year lower than that of persons of Japanese or Russian ancestry.

The key parameters estimated in the GSS data are reported in Table 8. I used a random effects estimator to allow for a group-specific component in the error term. Consider initially the results from the log wage regressions. The first row of the panel presents the ethnic capital model 
TABLE 7

SUMMARY CHARACTERISTICS OF THIRD GENERATION IN GSS, BY ETHNIC GROUP

Country of
Origin:
Austria
Belgium
Canada
China
Denmark
England
Finland
France
Germany
Greece
Hungary
Ireland
Italy
Japan
Mexico
Netherlands
Norway
Poland
Portugal
Romania
Scotland
Spain
Sweden
Switzerland
USSR
Yugoslavia

\begin{tabular}{c} 
Educatio \\
\hline 13.8 \\
13.2 \\
12.7 \\
18.0 \\
14.1 \\
13.8 \\
12.9 \\
13.4 \\
13.2 \\
14.0 \\
14.4 \\
13.5 \\
13.4 \\
15.3 \\
11.0 \\
13.0 \\
13.5 \\
13.6 \\
13.0 \\
14.7 \\
14.1 \\
12.2 \\
13.6 \\
13.0 \\
15.1 \\
13.3
\end{tabular}

$\begin{array}{rrrr}\begin{array}{r}\text { Father's } \\ \text { Education }\end{array} & \begin{array}{r}\text { Log } \\ \text { Wage }\end{array} & \begin{array}{r}\text { Father's } \\ \text { Log Wage }\end{array} & \begin{array}{r}\text { Sample } \\ \text { Size }\end{array} \\ 11.4 & 1.468 & 1.438 & 24 \\ 10.3 & 1.240 & 1.434 & 10 \\ 11.2 & 1.349 & 1.394 & 100 \\ 12.0 & 1.697 & 1.574 & 1 \\ 10.3 & 1.372 & 1.236 & 40 \\ 11.8 & 1.428 & 1.410 & 253 \\ 11.1 & 1.309 & 1.283 & 30 \\ 10.6 & 1.368 & 1.364 & 58 \\ 10.4 & 1.396 & 1.287 & 605 \\ 13.0 & 1.379 & 1.590 & 10 \\ 10.9 & 1.422 & 1.480 & 27 \\ 11.6 & 1.414 & 1.373 & 349 \\ 11.4 & 1.382 & 1.382 & 332 \\ 11.1 & 1.425 & 1.439 & 9 \\ 7.1 & 1.272 & 1.089 & 89 \\ 9.0 & 1.370 & 1.145 & 52 \\ 11.2 & 1.367 & 1.254 & 109 \\ 10.7 & 1.389 & 1.358 & 184 \\ 10.7 & 1.195 & 1.348 & 9 \\ 13.0 & 1.327 & 1.414 & 7 \\ 12.3 & 1.419 & 1.358 & 71 \\ 9.9 & 1.313 & 1.247 & 18 \\ 11.9 & 1.399 & 1.319 & 105 \\ 12.5 & 1.360 & 1.230 & 19 \\ 13.0 & 1.536 & 1.509 & 67 \\ 9.9 & 1.386 & 1.360 & 29\end{array}$


TABLE 8

INTERGENERATIONAL TRANSMISSION IN GSS

I. Educational Attainment Regressions

\begin{tabular}{|c|c|c|c|}
\hline Regression & $\begin{array}{l}\text { Parental } \\
\text { Education }\end{array}$ & $\begin{array}{c}\text { Mean Education } \\
\text { in Parent's } \\
\text { Generation }\end{array}$ & $\begin{array}{l}\text { Literacy } \\
\text { Rate of } 1910 \\
\text { Immigrants }\end{array}$ \\
\hline 1. & $(.0147)$ & $\left(.2669^{\star}\right.$ & $\cdots$ \\
\hline 2. & $\cdots$ & $\cdots$ & $\begin{array}{r}2.5280 \\
(1.7837)\end{array}$ \\
\hline 3. & $\begin{array}{l}.2589^{\star} \\
(.0147)\end{array}$ & $\cdots$ & $\begin{array}{l}1.5195 \\
(1.3678)\end{array}$ \\
\hline
\end{tabular}

II. Log Wage Regressions

\begin{tabular}{|c|c|c|c|c|}
\hline Regression & $\begin{array}{l}\text { Parental } \\
\text { Log Wage }\end{array}$ & $\begin{array}{c}\text { Mean Log Wage } \\
\text { in Parent's } \\
\text { Generation }\end{array}$ & $\begin{array}{c}\text { Mean Log Wage } \\
\text { of } 1910 \\
\text { Immigranes }\end{array}$ & $\underline{\mathrm{R}}^{2}$ \\
\hline 1. & $\begin{array}{l}.1630^{*} \\
(.0198)\end{array}$ & $(.1274)^{\star}$ & $\cdots$ & .097 \\
\hline 2. & $\cdots$ & $\cdots$ & $\left(.2155^{\star}\right.$ & .065 \\
\hline 3. & $\begin{array}{l}.1667^{\star} \\
(.0197)\end{array}$ & $\cdots$ & $(.1202)$ & .095 \\
\hline
\end{tabular}

\footnotetext{
Notes: Standard errors are reported in parentheses. The regressions are estimated using a random effects estimator. All regressions control for age, gender, region, metropolitan residence, and a vector of dumay variables indicating the year in which the GSS cross-section was drawn. The sample size is 2,197 for the education regressions and 1,970 for the log wage regressions.

* Statistically significant at the 5 percent level in a one-tailed test.
} 
as given by equation (6). The GSS data indicate that both the father's wages and the mean wages of the ethnic group in the father's generation are important determinants of the earnings of GSS respondents. The sum of the two coefficients, which estimates the rate of mean-convergence between the second and third generations, is approximately .46 .

The link between the earnings of the GSS grandchildren and the earnings of the immigrant grandparents is explored in the remaining rows. In particular, the second row reports the coefficient measuring the extent of mean-convergence between the grandparents and the children to be .22 . Because this statistic is approximately the square of .46 , the results suggest that the intergenerational transmission coefficient is relatively the same across any two generations.

Finally, the third row presents the estimated coefficients of equation (9), and shows that the average earnings of the 1910 immigrant groups has an independent effect on the skills of the grandchildren (although this effect is not very significant). If the model in (9) is correct, the parameter measuring mean-convergence between the 1910 immigrants and their children is approximately .41 (or the ratio $1202 / .2945$ ), almost the same as the rate of mean-convergence between the second and third generations. The GSS data, therefore, indicate that the coefficient measuring mean convergence in the log wages of ethnic groups is in the order of .4 to .5 , and is relatively constant across generations.

The top panel of Table 8 reveals an equally long-lasting impact of the 1910 literacy rate on the educational attainment of the GSS grandchildren. Row l estimates the rate of mean convergence in educational attainment to be .53. Rows 2 and 3 reveal that a 20 percentage point increase in the literacy rate of the 1910 immigrant group increases the educational attainment of 
the GSS respondent by .5 years if parental education is not held constant and by .3 years when parental education is included in the regression.

It is worth noting that there is a strong similarity in the estimated rates of meanconvergence in the Census and the GSS. In particular, the Census data suggest that a 10 percent increase in the wage of the immigrant group in 1910 increases the earnings of 1980 native ethnics (who proxy for their grandchildren) by 2.0 percent. The GSS results, which specifically focus on the sample of third-generation Americans, estimates the statistic to be 2.2 percent.

The estimated intergenerational correlation of 4 to .5 in the mean skills of ethnic groups implies that it might take four generations, or roughly 100 years, for the skill differences introduced by the Great Migration to disappear. This is a much slower rate of convergence than the within-group regression towards the mean (the within-group intergenerational correlation is in the order of .25 ). It is also a much slower rate of convergence than is experienced by members of different ethnic groups with similarly-skilled fathers (that correlation is also about .25). It is the combination of the influence of parental skills and the ethnic spillover which tends to delay the convergence of ethnic skill differentials for century.

\section{Black Intergenerational Mobility}

Because the paper focuses on the convergence of the skill differentials introduced by the Great Migration, I omitted the sample of American-born blacks from the study. It is often claimed that blacks differed from the persons who arrived during the Great Migration because the immigrants were able to improve their economic situation over time, but black economic status did not change appreciably across generations. I now evaluate the validity of this hypothesis by 
using the regression models estimated earlier to determine if the intergenerational mobility experienced by blacks differed from that experienced by the mainly white immigrant groups.

The skills of black workers in 1910 were substantially below those of white natives, and were also lower than the skills of most national origin groups. The literacy rate of blacks was 68.4 percent, and the log occupational wage was 6.006 (after standardizing for age and region of residence). By comparing these statistics with the corresponding numbers for white natives or for immigrant groups in Tables 2 and 3, it is evident that blacks started out the century at a substantial disadvantage. The literacy rate of blacks, for example, was nearly 30 percentage points below that of white natives and 15 percentage points below that of immigrants. Similarly, the wage of blacks was about 30 percent below that of immigrants as a group, and was lower than the wage of all but one of the immigrant groups (the exception being the Japanese).

Given these initial values, Table 9 uses the regression equations estimated in Census data to predict black intergenerational mobility. To understand the nature of the exercise, it is instructive to work through one of the rows in Table 9 in detail. Consider the first row, which predicts black educational attainment in 1940 as a function of the 1910 black literacy rate. If black intergenerational progress between 1910 and 1940 had been the same as that of the white ethnic groups in the Great Migration (as summarized by the regression in Table 5, row 1), the 1910 black literacy rate of 68.4 percent implies an educational attainment of 8.6 years in 1940. In fact, blacks only had 6.3 years of schooling in 1940. Black intergenerational mobility, therefore, was substantially slower than that of immigrants with the same initial conditions in 1910 .

A similar retardation of black economic progress is shown in row 3 , which predicts the 1940 black wage as a function of the 1910 black wage (based on the regression in Table 5, row 
TABLE 9

OUT-OF-SAMPLE PREDICTION FOR BLACK INTERGENERATIONAL MOBILITY

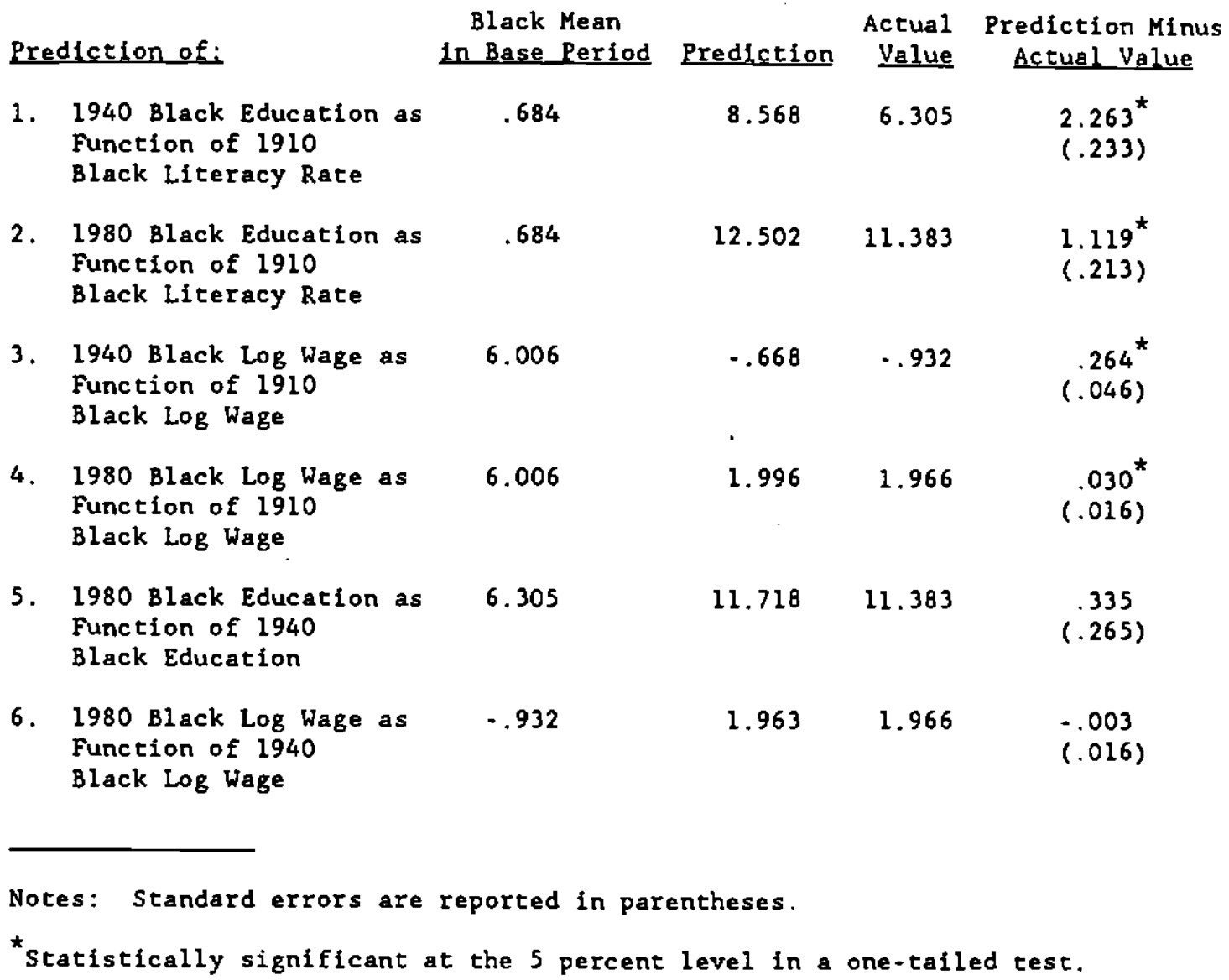


2). If blacks had experienced the same income mobility as the ethnic groups, the initial adjusted $\log$ wage of 6.006 implied a $1940 \log$ wage rate of -.668 . The actual black log wage was -.932 , or about 25 percent lower than the prediction.

Rows 2 and 4 of Table 9 use the 1910 initial conditions to predict black educational attainment and earnings in 1980 (using the regressions reported in Table 6, rows 1 and 2). These predictions, although still higher than actual black performance in 1980, are not as far off the mark as the 1940 predictions. In particular, given the 1910 initial conditions, blacks in 1980 should have had "only" 1.1 more year of schooling and 3 percent higher wage rates.

The very different implications of the 1940 and 1980 predictions suggests that black intergenerational mobility may have differed radically between the pre- and postwar periods. Rows 5 and 6 of Table 9 predict 1980 educational attainment and wages as a function of the 1940 black values (based on unreported regressions linking the 1980 earnings of third-generation ethnic groups to the 1940 earnings of second-generation Americans). These predictions are remarkably close to what was actually observed. The 1940 black education level of 6.3 years implies a 1980 education level of 11.7 years, only slightly higher than the 11.4 years reported by the 1980 Census; the 1940 black wage of -.932 implies a 1980 wage of 1.963 , almost the same as the actual black wage in 1980.

It is evident. therefore, that fundamental changes in the process guiding black mobility led to relatively similar intergenerational progress for blacks and for non-black ethnics in the postwar period. The shift in the structure that describes black intergenerational mobility may be related to improving school quality for blacks, to civil rights legislation, or to the migration of blacks from the rural South to manufacturing jobs in Northern cities (Lieberson, 1973; Card and Krueger, 
1992; Srnith and Welch, 1989; Heckman and Payner, 1989). Much further study, however, is required to determine why blacks began to "look like" non-black ethnics after 1940.

\section{Summary}

This paper analyzed the extent to which ethnic skill differentials converge in the long run. The analysis focused on the 32 national origin groups that made up the bulk of the $1880-1910$ Great Migration, and used the 1910,1940, and 1980 decennial Censuses, and the General Social Surveys, to trace out the economic experience of these groups throughout the 20th Century.

The empirical analysis yields a number of substantive findings. First, the Great Migration introduced huge ethnic skill differentials into the economy. Differences of 20 to 30 percentage points in literacy rates or wage differentials exceeding 30 percent were not uncommon. These skill differentials became important determinants of the skills and labor market success of the children and grandchildren of the Great Migration. A 20 percentage point differential in literacy rates among two immigrant groups in 1910, for instance, implied a 1 year difference in educational attainment in 1940, and a .5 year difference in educational attainment in 1980 . Similarly, a 20 percent wage differential between two groups in 1910 implied a 12 percent wage differential in 1940, and a 5 percent wage differential in 1980. Finally, the analysis documented that the intergenerational mobility of American-born blacks was roughly similar to that experienced by the white ethnic groups making up the Great Migration over the entire century, though much of the black mobility occurred after 1940 .

The slow convergence of ethnic skill differentials arises partly because ethnicity has spillover effects on the human capital accumulation process. In particular, the "quality" of the 
ethnic environment has an impact on the human capital of children above and beyond parental inputs. In other words, exposure to advantageous ethnic environments has a positive influence on the human capital accumulation process, while exposure to disadvantage environments has a negative influence (above and beyond the parental influence). These spillover effects retard intergenerational improvement for relatively disadvantaged ethnic groups, and slow down the deterioration of skills (i.e., the regression towards the mean) among the more advantaged groups.

In sum, ethnicity matters and it matters for a very long time. In fact, the results indicate that it may take four generations, or roughly 100 years, for the ethnic differentials introduced by the Great Migration to work themselves through the American economy. This result has obvious implications for the ongoing debate over immigration policy. As with the First Great Migration that arrived at the beginning of the 20th Century, the Second Great Migration that is arriving at the end of the 20th century is also composed of groups which differ greatly in their skills. If the intergenerational correlations estimated in this paper are constant over time, the results imply that current immigration is setting the stage for the ethnic differences in economic outcomes that are likely to be a dominant feature of labor markets in the United States throughout the next century. 


\section{REFERENCES}

Alba, Richard D. 1990. Ethnic Identity: The Transformation of White America. New Haven, Conn.: Yale University Press.

Barro, Robert J., and Xavier Sala-i-Martin. 1992. "Convergence." Journal of Political Economy, Vol. 100, No. 2 (April), pp. 223-251.

Blau, Francine. 1980. "Immigration and Labor Earnings in Early Twentieth Century America." Research in Population Economics, Vol. 2, pp. 21-41.

Borjas, George J. 1992. "Ethnic Capital and Intergenerational Mobility." Quarterly Journal of Economics, Vol. 107, No. 428 (February), pp. 123-150.

Borjas, George J. 1993. "The Intergenerational Mobility of Immigrants." Journal of Labor Economics, Vol. 11, No. 1, Pt. 1 (January), pp. 113-135.

Card, David, and Alan B. Krueger. 1992. "School Quality and Black-White Relative Earnings: A Direct Assessment." Quarterly Journal of Economics, Vol. 107, No. 428 (February), pp. 151-200.

Coleman, James S. 1988. "Social Capital in the Creation of Human Capital." American Journal of Sociology, Vol. 94, Supplement, pp. S95-S120.

Davis, James Allan, and Tom W. Smith. 1989. General Social Surveys, 1972-1989. Cumulative Codebook. Chicago, IL: National Opinion Research Center.

Douglas, Paul H. 1919. "Is the New Immigration More Unskilled than the Old?" Journal of the American Statistical Association. Vol. 16 (June), pp. 393-403.

Eichengreen, Barry and Gemery, Henry A. 1986. "The Earnings of Skilled and Unskilled Immigrants at the End of the Nineteenth Century." Journal of Economic History. Vol. 46, No. 2 (June), pp. $441-454$.

Farley, Reynolds. 1990. "Blacks, Hispanics, and White Ethnic Groups: Are Blacks Uniquely Disadvantaged?" American Economic Review Papers and Proceedings, Vol. 80, No. 2 (May), pp. 237-241

Glazer, Nathan, and Moynihan, Daniel P. 1963. Beyond the Melting Pot: The Negroes, Puerto

Ricans, Jews, Italians, and Irish of New York City. Cambridge, Mass.: M.I.T. Press.

Gordon, Milton. 1964. Assimilation and American Life. New York: Oxford University Press.

Heckman, James J., and Brook S. Payner. 1989. "Determining the Impact of Federal Antidiscrimination Policy on the Economic Status of Blacks: A Study of South Carolina." American Economic Review, Vol. 79. No. 1 (March), pp. 138-177. 
Higham, John. 1963. Strangers in the Land; Patterns of American Nativism, 1860-1925. New York: Atheneum.

Jenks, Jeremiah W., and W. Jett Lauck. 1917. The Immigration Problem. New York: Funk \& Wagnalls Co.

Jiobu, Robert Masao. 1990. Ethnicity and Inequality. AJbany, N.Y.: State University of New York Press.

Jones, Maldwyn Allen. 1960. American Immigration. Chicago: University of Chicago Press.

Lieberson, Stanley. 1973. "Generational Differences Among Blacks in the North." American Journal of Sociology, Vol. 79, No. 3 (November): 550-565.

Lieberson, Stanley, and Waters, Mary C. 1988. From Many Strands: Ethnic and Racial Groups in Contemporary America. New York: Russell Sage.

Lucas, Robert E. 1988. "On the Mechanics of Economic Development." Journal of Monetary Economics, Vol. 22, No. 1 (July), pp. 3-42.

Park, Robert. 1975. Race and Culture. Glencoe, IL: Free Press.

Perlmann, Joel. 1988. Ethnic Differences: Schooling and Social Structure Among the Irish. Italians, Jews, and Blacks in an American City 1880-1935. New York: Cambridge University Press.

Preston, Samuel H., and Michael R. Haines. 1991. Fatal Years: Child Mortality in Late Nineteenth Century America. Princeton, N.J.: Princeton University Press.

Romer, Paul M. 1986. "Increasing Returns and Long-Run Growth," Journal of Political Economy, Vol. 94, No. 6 (December), pp. 1002-1037.

Smith, James P., and Finis R. Welch. 1989. "Black Economic Progress After Myrdal," Journal of Economic Literature, Vol. 27, No. 2 (June), pp. 519-564.

Sollors, Werner. 1986. Beyond Ethnicity: Consent and Descent in American Culture. New York: Oxford University Press.

Steinberg. Stephen. 1989. The Ethnic Myth: Race. Ethnicity, and Class in America. Boston: Beacon Press.

Strong, Michael A., et al. User's Guide to the Public Use Sample, 1910 United States Census of Population. Mimeograph. Population Studies Center, University of Pennsylvania, 1989. 
U.S. Immigration and Naturalization Service. 1991. Statistical Yearbook of the Immigration and Naturalization Service, 1990. Washington, D.C.: U.S. Government Printing Office.

Wilson, William Julius. 1987. The Truly Disadvantaged: The Inner City, the Underclass, and Public Policy. Chicago: University of Chicago Press. 